\title{
Effect of intramammary infection on milk electrical conductivity in Murciano-Granadina goats
}

\author{
J. R. Díaz, ${ }^{\star 1}$ G. Romero, ${ }^{*}$ R. Muelas, ${ }^{*}$ M. Alejandro, ${ }^{*}$ and C. Peris $\dagger$ \\ *Departamento de Tecnología Agroalimentaria, Escuela Politécnica Superior de Orihuela, Universidad Miguel Hernandez, Ctra. Beniel, \\ 03312 Orihuela, Spain \\ †Instituto de Ciencia Animal, Universidad Politécnica de Valencia, Camino de Vera s/n, 46022 Valencia, Spain
}

\section{ABSTRACT}

Measurements of electrical conductivity (EC) of milk are used in mastitis detection in cows due to the low cost, possibility of automation, and rapid diagnosis, but the literature about EC measurement in goats is scarce. In this study, we studied the effect of the establishment of intramammary infection (IMI) on EC of goat milk by gland using daily measurements. Additionally, the effects on milk yield, somatic cell count (SCC), and mineral content were analyzed. Eight primiparous and 10 multiparous Murciano-Granadina goats free from IMI were included in the study. Health conditions of the participating animals were monitored for $16 \mathrm{~d}$ and then various unfavorable health situations that may arise on commercial farms were simulated to increase the chances of IMI. Once the IMI was confirmed, the experiment continued for another $16 \mathrm{~d}$. Statistical analysis was conducted using a linear mixed model considering several periods regarding the establishment of the infection and whether it affected one or both glands in the animal. The establishment of IMI caused a significant increase of EC, SCC, and chlorides in the infected glands, whereas the sodium:potassium ratio and the ratio of EC between collateral glands showed significant increases only in bilaterally infected animals. The microorganisms that caused greater increases of EC were Staphylococcus aureus and a gram-negative bacterium. Changes due to other isolated microorganisms (coagulase-negative staphylococci and streptococci) were small. No significant differences in milk yield were determined. The significant effect of infection on EC in the affected glands suggests that the use of a system based on daily readings of EC could be useful in IMI detection of goats.

Key words: intramammary infection, goat milk, electrical conductivity

Received July 7, 2011.

Accepted October 6, 2011.

${ }^{1}$ Corresponding author: jr.diaz@umh.es

\section{INTRODUCTION}

Measurements of electrical conductivity (EC) on milk have been used in dairy cattle as a tool for detecting subclinical and early clinical mastitis before clinical signs appear. Rapid detection has helped to achieve high bacteriological cure rates due to early treatment (Milner et al., 1997), with positive economic effects of shorter treatments, less milk loss, and better milk quality. Furthermore, detection of mastitis by EC measurement of milk has the advantage of automation in the milking parlor, offering rapid results that help improve milk quality and safety. Studies in cows showed that EC in milk is affected by cow-level factors and factors other than mastitis (e.g., stage of lactation, parity; Hamann and Zecconi, 1998). These results implied that global thresholds (used for all animals at any moment) were not adequate for mastitis detection. Better results are obtained when daily variations of $\mathrm{EC}$ in a gland were considered in the algorithms, alone or combined with other variables (yield or temperature); most studied methods used comparison of gland EC with moving average of previous days (Lansbergen et al., 1994; Zecconi et al., 2004; Cavero et al., 2007; Kamphuis et al., 2008) and comparison with EC of collateral glands (Maatje et al., 1992, 1997; Lien et al., 2005). Other methods include several variables and more complex algorithms (neuronal net, tracking signal method, fuzzy logic) but the results are similar to those mentioned above (Nielen et al., 1995a,b; De Mol et al., 1999; Mele et al., 2001; Cavero et al., 2006, 2008).

In goats, published studies on the effect of mastitis on EC are scarce. The results of Ying et al. (2004) in studies with different breeds of goats were contradictory. They observed that EC increased with infection in Saanen goats (from $5.6 \mathrm{mS} / \mathrm{cm}$ in healthy animals to 5.8 $\mathrm{mS} / \mathrm{cm}$ in infected ones), whereas EC decreased with infection in Alpine goats (from $6.1 \mathrm{mS} / \mathrm{cm}$ for healthy goats to $5.4 \mathrm{mS} / \mathrm{cm}$ in infected ones). A previous study of this research group (Díaz et al., 2011), using monthly measurements of EC, showed that several factors other than mastitis were related to EC in goats (individual variation of $\mathrm{EC}$, farm, parity, and stage of lactation). 
These results implied that when a unique threshold of EC was used to discriminate glands with mastitis, a low sensitivity resulted, as was shown in cows.

The current study was carried out to analyze the effect of the establishment of IMI on daily gland milk EC measurements of Murciano-Granadina goats.

\section{MATERIALS AND METHODS}

\section{Animal Management}

The experiment was carried out at the Educational Farm of the Escuela Politécnica Superior de Orihuela (Miguel Hernandez University, Spain). Characteristics related to farm included intensive management of the animals (Murciano-Granadina goats), permanent stabling, one parturition per year, artificial feeding from birth, and mechanical milking once a day (in the morning). Milking parameters were rate of 90 pulsations per minute, vacuum level of $40 \mathrm{kPa}$, and $60 \%$ pulsation ratio. Animals were fed with a commercial mixture (unifeed system; Alimer Cooperative, Lorca, Spain) for high-production goats and feed was constant during the whole study (quantity and quality).

\section{Experimental Design and Analyzed Variables}

Enrollment Criteria. During the pre-experimental phase (1 wk before the experiment), 56 goats underwent 2 sampling days in their third month of lactation. Bacteriological analyses (aseptic sampling before milking), yield, EC, and SCC of milk (representative samples of the whole milking) were determined by gland. From the results of this sampling, 18 goats ( 8 primiparous and 10 multiparous) whose glands were free of IMI and yield was 1.8 to $2.8 \mathrm{~L}$ were selected. Average yield of the animals in the first sampling day was $2.24 \mathrm{~L}( \pm 0.44 \mathrm{~L})$.

Definition of Health Status of the Gland. To determine the health status of the gland, both bacteriological analysis and SCC results were considered. A gland was defined as having bacterial mastitis when bacteriological analyses were positive for IMI. When the bacteriological analysis was negative and SCC was $>1,000,000$ cells $/ \mathrm{mL}$ on 2 or more consecutive sampling days and for nonphysiological causes, it was considered as unspecific. A physiologic increase in SCC (e.g., due to estrus; Christodoulopoulos et al., 2008) was defined when bacteriological analysis was negative and SCC increased in both glands for a maximum of 3 consecutive days that was followed by SCC $<1,000,000$ cells $/ \mathrm{mL}$ in a subsequent analysis, or end of lactation occurred. A gland was considered free from mastitis with negative bacterial culture and if the increase in SCC was due to physiological causes.
Data Collection and Analyzed Variables. The experimental phase was divided in half. During the first sub-phase (16 d), daily sampling was done to obtain information regarding the studied variables before the possible establishment of infection. After this first experimental sub-phase, various unfavorable health situations (UHS) for the mammary gland were simulated for $5 \mathrm{~d}$, consisting of situations that could occur on any commercial farm in which the exposure of teats to pathogens is increased during milking, such as milking a healthy goat after a goat with IMI favoring a wet milking and inverse milk flow; increasing the milking vacuum level to $44 \mathrm{kPa} ; 3$ min of overmilking; and elimination of iodine teat dipping after the milking. The second experimental sub-phase took place over the $16 \mathrm{~d}$ after IMI was established in every animal, as promoted by the UHS.

Variables were analyzed by gland in every animal: bacteriology (samples aseptically collected prior to the milking), EC, SCC, milk yield, and concentrations of chloride, sodium, and potassium at different frequencies in a representative sample of the milking.

Frequency of bacteriological sampling was weekly before UHS. After the beginning of UHS, 1 analysis was done and repeated every 2 to $3 \mathrm{~d}$ to confirm the presence and persistence of infection. Milk samples for bacteriological analysis $(5 \mathrm{~mL})$ were obtained aseptically from teats carefully cleaned with $70 \%$ ethanol, discarding the first 3 streams of foremilk, and placed into sterile tubes; these were kept at $4^{\circ} \mathrm{C}$ for a maximum of $12 \mathrm{~h}$ until analysis, used for the bacteriological analysis, and then frozen until the end of the experiment. Twenty microliters of each sample was plated on blood agar plates (5\% washed sheep erythrocytes; bioMèrieux, Lyon, France). The plates were incubated aerobically at $37^{\circ} \mathrm{C}$ and examined at 24,48 , and $72 \mathrm{~h}$. Cultures with 5 or more identical colonies were considered positive for IMI. Bacteria were identified according to the National Mastitis Council recommendations (Harmon et al., 1990). Presumptive identification of bacterial group was done for positive samples: coagulase-positive staphylococci, CNS, streptococci, gram-negative bacilli, and others (e.g., Corynebacterium). Gram staining was done and the catalase test was analyzed for gram-positive microorganisms. For staphylococci, the bacterial species were identified using the apiStaph kit (bioMèrieux, Craponne, France).

The yield $(\mathrm{mL})$ was registered daily with an automated yield recorder installed in the milking parlor (Metatron, Gea-Westfalia-Surge, Bönen, Germany); the device collected a representative sample from the milking of the gland that was used to measure the rest of the variables. 
Electrical conductivity $(\mathrm{mS} / \mathrm{cm})$ was a continuous variable registered daily using a laboratory conductivity meter (GLP 32, Crison, Alella, Spain) equipped with a PT100 temperature probe and reading compensated at $25^{\circ} \mathrm{C}$.

Somatic cell count $(\times 1,000$ cells $/ \mathrm{mL})$ was a continuous variable analyzed on samples kept in azidiol, using fluoro-opto-electronic method (Fossomatic 90, Foss Electric, Hillerød, Denmark) in the Inter-professional Dairy Laboratory of the Community of Valencia (LICOVAL, Valencia, Spain). Prior to UHS, SCC was analyzed weekly until $3 \mathrm{~d}$ before UHS (2 analyses), and then daily until $11 \mathrm{~d}$ after establishment of the infection, and finally on d 13, 15, and 16 .

Mineral content (chloride, sodium, and potassium) was analyzed from samples of 13 goats ( 5 goats that remained free from infection, 5 with unilateral infection, and 3 with bilateral infection): 2 analyses before the infection ( 7 and $3 \mathrm{~d}$ before) and 4 analyses after infection $(1,4,7$, and $11 \mathrm{~d}$ after infection). Determination of chloride (mg/L) was done by using Mohr's method adapted to milk (AOAC, 1995) and the determination of sodium and potassium $(\mathrm{mg} / \mathrm{L})$ was done with flame photometry (PFP, Jenway, Stone, United Kingdom).

\section{Treatment of the Data and Statistical Analysis}

The effect of IMI on EC, SCC, yield, and mineral content (chlorides, sodium, potassium, and sodium:potassium ratio) of milk along different periods around the establishment of the infection was studied. In addition, we studied the effect on the ratio of milk EC in collateral glands of an animal (RELEC), where RELEC = milk EC of infected gland divided by milk $\mathrm{EC}$ of healthy gland in unilaterally infected goats, and RELEC $=$ milk EC of right gland divided by milk EC of left gland in bilaterally infected goats and goats free from infection.

First, the distribution of variables was analyzed using box-plots, histograms, and normal probability plots. Values of EC $(\mathrm{mS} / \mathrm{cm})$ and $\mathrm{SCC}(\times 1,000$ cells $/ \mathrm{mL})$ were transformed into base 10 logarithm to normalize their distributions.

The association between the explanatory variables and EC, SCC, and yield was assessed using stepwise linear mixed model procedures. Explanatory variables and their interaction were included in the final models (Proc Mixed; SAS Institute, 2002). The explanatory variables considered were infective evolution of the goat (INF, 4 levels, $0=$ both collateral mammary glands free from infection during the whole experimental period; $1=$ mammary gland infected during the experiment whose collateral gland stayed free from infection; $2=$ mammary gland free from infection whose collateral gland became infected during the experiment; 3 = both collateral mammary glands became infected during the experimental period); the period in relation to the occurrence of the infection (PER, 8 levels, 1 $=16-13 \mathrm{~d}$ before the infection, $2=12-9 \mathrm{~d}$ before the infection, $3=8-5 \mathrm{~d}$ before the infection, $4=4-1 \mathrm{~d}$ before the infection, $5=1-4 \mathrm{~d}$ postinfection, $6=5-8$ d postinfection, $7=9-12 \mathrm{~d}$ postinfection, $8=13-16 \mathrm{~d}$ postinfection); and the interaction of INF with PER. To account for the clustering of mammary glands within animals (Barkema et al., 1997), gland nested in goat and goat were considered random terms. In addition, a compound symmetry covariance structure was used to account for the repeated measurements over time on the same mammary glands. The model using this hierarchical structure provided the best fit for the data at every studied variable compared with different models considering other covariance and hierarchical structures (as assessed using Bayesian and Akaike's information criteria).

As only multiparous goats were infected during the experiment, the effect of lactation number was not included in the models. For analysis of the behavior of the variables in healthy glands among periods relative to infection, 2 healthy reference glands with similar yield were assigned to each infected gland, adopting the same day of reference to establishment of infection and periods relatives to it.

The association between each explanatory variable and RELEC was assessed using the same procedure adopted in the previous mentioned variables. A final linear mixed model (Proc Mixed, SAS Institute, 2002) included the following explanatory variables: PER (8 levels, as defined in EC analysis), infective evolution of the goat $(3$ levels, $0=$ both collateral glands free from infection during the whole experimental period; 1 $=$ unilateral infection during the experimental period; $2=$ both collateral glands became infected during the experimental period) and the interaction of infective evolution of the goat with PER, including goat as a random term. A compound symmetry covariance structure was used to account for the repeated measurements over time on the same goats.

The association between explanatory variables and mineral content variables was assessed using stepwise linear mixed model procedures (Proc Mixed, SAS Institute, 2002), including in the final model variables and their interaction, period in relation with the occurrence of the infection [PER, 2 levels: one before the infection (2 sampling days) and other postinfection (4 sampling days)], infective evolution of the goat (INF, 4 levels: the same as used in EC analysis), and the interaction of INF with PER, including goat and gland nested to goat as random terms. A compound symmetry covari- 
Table 1. Electrical conductivity of goat milk from glands (average $\pm \mathrm{SD}, \mathrm{mS} / \mathrm{cm}$ ) of infected glands in different periods around the establishment of infection, by pathogen

\begin{tabular}{|c|c|c|c|c|}
\hline \multirow[b]{2}{*}{ Infection/pathogen } & \multirow{2}{*}{$\begin{array}{c}\text { Glands, } \\
\text { no. }\end{array}$} & \multicolumn{3}{|c|}{ Days around establishment of infection } \\
\hline & & $4 \mathrm{~d}$ before & $1-4 \mathrm{~d}$ after & $5-8 \mathrm{~d}$ after \\
\hline \multicolumn{5}{|l|}{ Unilateral } \\
\hline Staphylococcus caprae & 1 & $5.32 \pm 0.09$ & $5.30 \pm 0.04$ & $5.49 \pm 0.09$ \\
\hline Streptococcus spp. & 1 & $5.18 \pm 0.03$ & $5.37 \pm 0.16$ & $5.46 \pm 0.24$ \\
\hline Staphylococcus xylosus & 2 & $5.94 \pm 0.34$ & $6.03 \pm 0.24$ & $5.99 \pm 0.36$ \\
\hline Staphylococcus chromogenes & 1 & $5.41 \pm 0.09$ & $5.37 \pm 0.05$ & $5.53 \pm 0.06$ \\
\hline Gram-negative bacilli & 1 & $5.09 \pm 0.14$ & $5.52 \pm 1.25$ & $5.32 \pm 0.09$ \\
\hline \multicolumn{5}{|l|}{ Bilateral } \\
\hline Staphylococcus aureus & 1 & $5.58 \pm 0.09$ & $8.61 \pm 1.65$ & $7.75 \pm 1.05$ \\
\hline Staph. xylosus & 2 & $6.04 \pm 0.06$ & $6.09 \pm 0.54$ & $6.13 \pm 0.43$ \\
\hline Staph. caprae & 2 & $5.71 \pm 0.09$ & $5.61 \pm 1.65$ & $5.47 \pm 0.13$ \\
\hline Staphylococcus spp. & 1 & $6.54 \pm 0.09$ & $6.48 \pm 0.02$ & $6.29 \pm 0.15$ \\
\hline
\end{tabular}

ance structure was used to account for the repeated measurements over time on the same mammary glands.

\section{RESULTS}

\section{Incidence and Prevalence of IMI}

The prevalence and incidence of bacteriological mastitis after UHS was $50 \%$ for goats and $33.3 \%$ for glands. Six multiparous goats were infected unilaterally and 3 bilaterally (a total of 12 glands). Unilateral gland infections were caused by several pathogens (Table 1): 3 Staphylococcus species, 1 gram-negative microorganism (isolated in 1 sample), and Streptococcus spp. (isolated in 1 sample). In bilateral infections, all isolated pathogens were Staphylococcus species. Staphylococcus xylosus was the most frequent staphylococcus in the whole study (n $=4$ ). It was not possible to identify the species in one of the glands, because of a result of the biochemical test that did not correspond with any species identified by the test used. Only in the presence of major pathogens (gram-negative bacillus and Staphylococcus aureus) was a high increase of EC was determined, and no relevant increase was observed with the other pathogens after the establishment of infection. No cases of unspecific mastitis were observed.

\section{Factors Associated with Studied Variables of Milk}

The period regarding the establishment of the infection (PER) was significant for EC, as well as the interaction of INF with PER; INF was not significant by itself. For SCC, all explanatory variables included in the model were significant at the $P<0.05$ level. For yield, PER and INF were significant; the interaction of INF with PER was not significant, which indicates that yield behavior along periods was similar at all INF levels (Table 2).

Only infected glands (INF $=1,3)$ showed an increase of EC after infection occurred (Table 3); in bilateral infected glands (INF $=3$ ), the EC increase was significant in the first period after the establishment of the infection (d 1-4 postinfection). However, in unilateral infected glands $(\mathrm{INF}=1)$, the EC increase was not significant until d 5 to 8 postinfection. For glands that remained free from infection with the collateral gland infected (INF $=2$ ), no significant differences were determined, although we observed a tendency of the EC to increase once the collateral gland became infected.

Somatic cell count fluctuated slightly over time in glands free from infection (INF $=0,2$ ), with no significant differences between the before and after infection periods (Table 4$)$. In infected glands $(\mathrm{INF}=1,3)$, a significant increase was determined after the infection, which was not observed in collateral healthy glands $(\mathrm{INF}=2)$ or in glands from goats free from infection $(\mathrm{INF}=0)$. For unilaterally infected glands $(\mathrm{INF}=1)$, an increase in SCC occurred between d 16 and 13 before infection because of a physiological increase that did not increase EC. During the preinfection period,

Table 2. $F$-values $(F)$ and $P$-values of electrical conductivity, RELEC, SCC, and yield of goat milk from glands ${ }^{1}$

\begin{tabular}{|c|c|c|c|c|c|c|c|c|}
\hline Fixed effect & \multicolumn{2}{|c|}{ LEC } & \multicolumn{2}{|c|}{ RELEC } & \multicolumn{2}{|c|}{ LSCC } & \multicolumn{2}{|c|}{ Yield } \\
\hline Infective status & 1.22 & 0.3022 & 3.10 & 0.0748 & 25.20 & $<0.0001$ & 3.06 & 0.0273 \\
\hline Infective status $\times$ period & 4.20 & $<0.0001$ & 8.08 & $<0.0001$ & 4.92 & $<0.0001$ & 1.17 & 0.2699 \\
\hline
\end{tabular}

${ }^{1}$ RELEC = electrical conductivity $(\mathrm{EC})$ rate of collateral glands $(\mathrm{n}=542) ; \mathrm{LEC}=$ base 10 logarithm of EC $(\mathrm{n}=1,096) ;$ LSCC $=$ base 10 logarithm of SCC $(\mathrm{n}=684)$; yield $=$ milk yield $(\mathrm{n}=1,096)$. 


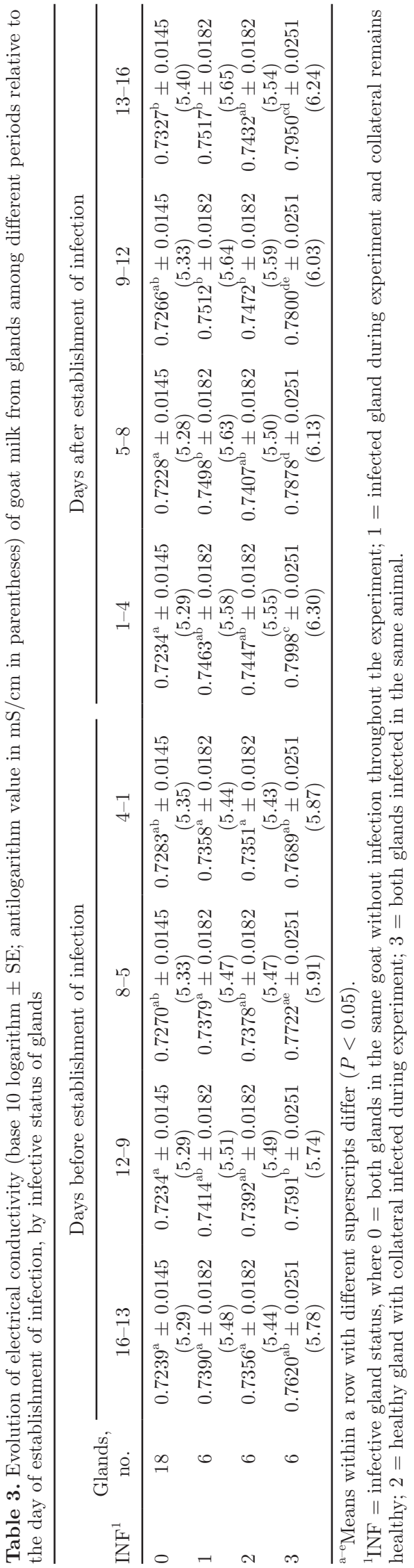

these glands had an SCC higher than that of glands free from infection, which then increased abruptly after infection. For the collateral healthy glands, the increase occurred after 5 to $8 \mathrm{~d}$, probably influenced by the collateral infected glands, in a similar way to EC. A similar observation was made for bilaterally infected glands during the intervals from 16 to $13 \mathrm{~d}$ and from 12 to $9 \mathrm{~d}$ before the infection; during these periods an increase in SCC occurred, whereas for the remaining preinfection periods (d 8-5 and 4-1 before infection) the SCC was significantly lower than after the infection.

Variables PER and INF were significant factors on yield analysis, although the interaction of both variables was not significant, indicating that yield in various stages of infection was not affected differently due to the establishment of the infection.

The establishment of infection increased RELEC in bilateral mastitis in approximately 18\% (Table 5); in unilateral mastitis, no significant changes were observed. Moreover, RELEC was more stable than EC in preinfection periods; thus, no significant differences were observed during the intervals before the establishment of the infection.

Regarding mineral content, establishment of infection caused changes only in chloride content and sodium:potassium ratio (Table 6). A significant increase associated with PER was determined for infected glands ( $\mathrm{INF}=1,3$ ); chloride values increased significantly after the infection, which was not observed in glands that remained free from infection (Table 7). For sodium:potassium, the interaction of both factors was significant, and significant differences were only observed in the glands of animals with bilateral infection $(\mathrm{INF}=3)$.

\section{DISCUSSION}

In this study, a high incidence of IMI was found, leading to high prevalence in comparison with other published results in the same geographical area and breed of goat (Contreras et al., 1995, 1997); high incidence was due to the techniques used to increase the probability of infection, as intended. The isolated pathogens corresponded to the causal agents of IMI in MurcianoGranadina goats in the geographical area where the study was carried out (Contreras et al., 1997).

In line with multiple studies in dairy cattle (Fernando et al., 1982, 1985; Hillerton and Walton, 1991; Holdaway et al., 1996; Bruckmaier et al., 2004) and results obtained in Saanen goats (Ying et al., 2004), the establishment of infection caused significant increases of milk EC in the infected glands, mainly in bilaterally infected glands. These increases of EC were accompanied by significant increases of chloride content 
Table 4. Evolution of SCC (base 10 logarithm \pm SE; antilog LSCC, $\times 1,000$ cell $/ \mathrm{mL}$, in parentheses) of goat milk from glands among different periods relative to establishment of infection, by infective status of glands

\begin{tabular}{|c|c|c|c|c|c|c|c|c|c|}
\hline \multirow[b]{2}{*}{$\mathrm{INF}^{1}$} & \multirow{2}{*}{$\begin{array}{l}\text { Glands, } \\
\text { no. }\end{array}$} & \multicolumn{4}{|c|}{ Days before establishment of infection } & \multicolumn{4}{|c|}{ Days after establishment of infection } \\
\hline & & $16-13$ & $12-9$ & $8-5$ & $4-1$ & $1-4$ & $5-8$ & $9-12$ & $13-16$ \\
\hline 0 & 18 & $\begin{array}{c}5.06^{\text {abcd }} \pm 0.14 \\
(115)\end{array}$ & $\begin{array}{c}5.37^{\text {bd }} \pm 0.10 \\
(234)\end{array}$ & $\begin{array}{l}5.07^{\mathrm{c}} \pm 0.09 \\
(116)\end{array}$ & $\begin{array}{l}5.23^{\mathrm{d}} \pm 0.07 \\
(170)\end{array}$ & $\begin{array}{c}5.14^{\text {acd }} \pm 0.07 \\
(139)\end{array}$ & $\begin{array}{l}5.12^{\mathrm{ac}} \pm 0.07 \\
(132)\end{array}$ & $\begin{array}{l}5.12^{\text {acd }} \pm 0.07 \\
(131)\end{array}$ & $\begin{array}{c}5.16^{\text {abcd }} \pm 0.08 \\
(146)\end{array}$ \\
\hline 1 & 6 & $\begin{array}{c}5.81^{\mathrm{ab}} \pm 0.33 \\
(649)\end{array}$ & $\begin{array}{l}5.63^{\mathrm{a}} \pm 0.15 \\
(432)\end{array}$ & $\begin{array}{l}5.37^{\mathrm{a}} \pm 0.18 \\
(231)\end{array}$ & $\begin{array}{c}5.65^{\mathrm{a}} \pm 0.11 \\
(443)\end{array}$ & $\begin{array}{l}6.28^{\mathrm{b}} \pm 0.11 \\
(1,885)\end{array}$ & $\begin{array}{l}6.09^{\mathrm{bc}} \pm 0.11 \\
(1,246)\end{array}$ & $\begin{array}{l}6.01^{\mathrm{c}} \pm 0.11 \\
(1,031)\end{array}$ & $\begin{array}{l}6.14^{\mathrm{bc}} \pm 0.12 \\
(1,381)\end{array}$ \\
\hline 2 & 6 & $\begin{array}{l}6.05^{\mathrm{ab}} \pm 0.33 \\
(1,135)\end{array}$ & $\begin{array}{c}5.71^{\mathrm{ab}} \pm 0.15 \\
(517)\end{array}$ & $\begin{array}{l}5.49^{\mathrm{a}} \pm 0.18 \\
(315)\end{array}$ & $\begin{array}{l}5.72^{\mathrm{ab}} \pm 0.11 \\
\quad(527)\end{array}$ & $\begin{array}{c}5.73^{\mathrm{ab}} \pm 0.11 \\
(565)\end{array}$ & $\begin{array}{l}5.85^{\mathrm{b}} \pm 0.11 \\
(715)\end{array}$ & $\begin{array}{l}5.87^{\mathrm{b}} \pm 0.11 \\
(744)\end{array}$ & $\begin{array}{l}5.70^{\mathrm{ab}} \pm 0.12 \\
(505)\end{array}$ \\
\hline 3 & 6 & $\begin{array}{c}5.98^{\mathrm{abd}} \pm 0.15 \\
(952)\end{array}$ & $\begin{array}{c}6.19^{\mathrm{bcd}} \pm 0.16 \\
(1,536)\end{array}$ & $\begin{array}{c}5.96^{\mathrm{ab}} \pm 0.13 \\
(909)\end{array}$ & $\begin{array}{l}5.87^{\mathrm{a}} \pm 0.13 \\
(739)\end{array}$ & $\begin{array}{l}6.34^{\mathrm{c}} \pm 0.12 \\
(2,201)\end{array}$ & $\begin{array}{l}6.29^{\mathrm{c}} \pm 0.13 \\
(1,946)\end{array}$ & $\begin{array}{l}6.27^{\mathrm{cd}} \pm 0.15 \\
(1,881)\end{array}$ & $\begin{array}{l}6.25^{\mathrm{cd}} \pm 0.15 \\
(1,786)\end{array}$ \\
\hline
\end{tabular}

${ }^{\mathrm{a}-\mathrm{d}}$ Means within a row with different superscripts differ $(P<0.05)$

INF $=$ infective gland status, where $0=$ both glands in the same goat without infection throughout the experiment; $1=$ infected gland during experiment and collateral remains healthy; $2=$ healthy gland with collateral infected during experiment; $3=$ both glands infected in the same animal.

Table 5. Evolution of goat milk RELEC ${ }^{1}$ (mean $\pm \mathrm{SE}$ ) among different periods relative to establishment of infection, by infective status of goats

\begin{tabular}{|c|c|c|c|c|c|c|c|c|c|}
\hline \multirow[b]{2}{*}{$\mathrm{INFCAB}^{2}$} & \multicolumn{4}{|c|}{ Days before establishment of infection } & \multicolumn{4}{|c|}{ Days after establishment of infection } & \multirow{2}{*}{$\begin{array}{c}\text { Significance } \\
\text { level }\end{array}$} \\
\hline & $16-13$ & $12-9$ & $8-5$ & $4-1$ & $1-4$ & $5-8$ & $9-12$ & $13-16$ & \\
\hline 0 & $1.002 \pm 0.015$ & $1.007 \pm 0.015$ & $1.000 \pm 0.015$ & $0.992 \pm 0.015$ & $1.004 \pm 0.015$ & $1.004 \pm 0.015$ & $0.999 \pm 0.015$ & $1.004 \pm 0.015$ & NS \\
\hline 1 & $1.008 \pm 0.019$ & $1.005 \pm 0.019$ & $1.000 \pm 0.019$ & $1.000 \pm 0.019$ & $1.008 \pm 0.019$ & $1.022 \pm 0.019$ & $1.010 \pm 0.019$ & $1.019 \pm 0.019$ & NS \\
\hline 2 & $1.009^{\mathrm{a}} \pm 0.027$ & $0.988^{\mathrm{a}} \pm 0.027$ & $0.998^{\mathrm{a}} \pm 0.027$ & $1.008^{\mathrm{a}} \pm 0.027$ & $1.189^{\mathrm{b}} \pm 0.027$ & $1.134^{\mathrm{c}} \pm 0.027$ & $1.083^{\mathrm{d}} \pm 0.027$ & $1.100^{\mathrm{cd}} \pm 0.029$ & 0.05 \\
\hline
\end{tabular}

${ }^{\mathrm{a}-\mathrm{d}}$ Means within a row with different superscripts differ $(P<0.05)$.

${ }^{1}$ RELEC $=$ electrical conductivity ratio of collateral glands.

${ }^{2} \mathrm{INFCAB}=$ infective goat status, where $0=$ both glands without infection throughout the experiment in the animal; $1=1$ gland infected during experiment and collateral remains healthy; 2 = both glands infected in the animal. 
DÍAZ ET AL.

Table 6. $F$-values $(F)$ and $P$-values of chloride, sodium, potassium, and sodium:potassium of goat milk from glands (n $=156$ observations)

\begin{tabular}{|c|c|c|c|c|c|c|c|c|}
\hline Fixed effect & \multicolumn{2}{|c|}{ Chloride } & \multicolumn{2}{|c|}{ Sodium } & \multicolumn{2}{|c|}{ Potassium } & \multicolumn{2}{|c|}{ Sodium:potassium } \\
\hline Infective status & 2.11 & 0.1013 & 0.70 & 0.5524 & 0.23 & 0.8787 & 0.31 & 0.8163 \\
\hline Infective status $\times$ period & 1.75 & 0.1591 & 1.36 & 0.2568 & 1.05 & 0.3740 & 3.64 & 0.0142 \\
\hline
\end{tabular}

and sodium:potassium ratio, in line with Fernando et al. (1982, 1985) and Díaz et al. (2011), who observed that chlorides explain the higher variance of EC in cow and goat milk, respectively. The greater increases of EC were found for bilateral infected glands where increases of both variables (chlorides and sodium:potassium) were observed, whereas for unilateral infected glands, the EC increase was lower, with only chlorides content being increased. This result implies that the bloodmilk barrier was more affected in bilateral infected glands than in unilateral infected glands, changing sodium:potassium from values that are considered normal in milk (0.3; Linzell and Peaker, 1971) to values $>0.4$, which contributed to a greater increase in EC.

For RELEC, no significant increases were determined in healthy animals or in unilaterally infected ones, only being significant in bilaterally infected animals. This finding is explained by the lower response for EC in unilateral infected glands compared with bilateral infected glands, as well as the small increase of EC observed in the collateral healthy glands $(\mathrm{INF}=2)$. These results are in agreement with those obtained by Hillerton and Walton (1991) in dairy cows, in which an effect was observed on the collateral healthy gland, which was explained by the possible passage of the bacterial toxin into the blood and subsequent transmission to the adjacent healthy gland to exert the toxic effect. Both responses considered together implied that RELEC, a ratio of both glands, did not increase sufficiently to show significant increase in unilateral infected glands. However, significant increases in RELEC were deter- mined if bilateral infection occurred, explained by the stronger effect of the infection in bilaterally infected animals compared with unilaterally infected ones, added to a greater effect of IMI on EC in one gland compared with the adjacent one.

Because significant increases of EC occurred with the establishment of infection in goats, it should be possible to use this parameter for detecting IMI in dairy goats, particularly if EC is measured daily by animal, as is done in dairy cattle (Maatje et al., 1992, 1997; Lansbergen et al., 1994; Nielen et al., 1995a,b; De Mol et al., 1999; Zecconi et al., 2004; Lien et al., 2005; Cavero et al., 2006, 2007; Kamphuis et al., 2008). These methods, compared with the use of a global threshold from isolated measurements of $\mathrm{EC}$, have the advantage of detection of the exact moment of EC increasing caused by the infection. Another advantage is that the effects of factors other than IMI (e.g, farm, stage of lactation, parity) are avoided when the data are compared with previous values from the same animal. Finally, the most valuable characteristic of these algorithms is that they model intrinsic daily individual variation of EC that occurs at physiological conditions, avoiding its effect on mastitis detection.

The variable RELEC showed significant differences after infection only in bilateral infected goats; its use in algorithms for mastitis detection would not add sensitivity compared with EC algorithms. Somatic cell count increased particularly in bilateral infections in agreement with values of EC. Similar results were obtained in dairy cattle (Bruckmaier et al., 2004; Yildiz et

Table 7. Chloride and sodium:potassium (mean \pm SE) by infective status of glands and period relative to establishment of infection of goat milk from glands

\begin{tabular}{|c|c|c|c|c|c|}
\hline \multirow[b]{2}{*}{$\mathrm{INF}^{1}$} & \multirow[b]{2}{*}{$\begin{array}{c}\text { Glands, } \\
\text { no. }\end{array}$} & \multicolumn{2}{|c|}{ Chloride, $\mathrm{mg} / \mathrm{L}$} & \multicolumn{2}{|c|}{ Sodium:potassium } \\
\hline & & $\begin{array}{l}\text { Before } \\
\text { infection }\end{array}$ & $\begin{array}{c}\text { After } \\
\text { infection }\end{array}$ & $\begin{array}{l}\text { Before } \\
\text { infection }\end{array}$ & $\begin{array}{c}\text { After } \\
\text { infection }\end{array}$ \\
\hline 0 & 10 & $1,928 \pm 71$ & $1,933 \pm 66$ & $0.3119 \pm 0.0349$ & $0.3238 \pm 0.0331$ \\
\hline 1 & 5 & $1,891^{\mathrm{a}} \pm 88$ & $2,018^{\mathrm{b}} \pm 76$ & $0.3345 \pm 0.0506$ & $0.3123 \pm 0.0470$ \\
\hline 2 & 5 & $1,834 \pm 85$ & $1,927 \pm 76$ & $0.3123 \pm 0.0494$ & $0.3012 \pm 0.0468$ \\
\hline 3 & 6 & $2,082^{\mathrm{a}} \pm 91$ & $2,213^{\mathrm{b}} \pm 87$ & $0.3201^{\mathrm{a}} \pm 0.0455$ & $0.4039^{\mathrm{b}} \pm 0.0431$ \\
\hline
\end{tabular}

$\overline{\mathrm{a}, \mathrm{b}}$ Means within a row with different superscripts differ $(P<0.05)$.

${ }^{1} \mathrm{INF}=$ infective gland status, where $0=$ both glands in the same goat without infection throughout the experiment; 1 = infected gland during experiment and collateral remains healthy; $2=$ healthy gland with collateral infected during experiment; 3 = both glands infected in the same animal. 
al., 2006), allowing us to assume that EC can be used as an indicator of gland damage, which consequently denotes the presence of mastitis. Increases of SCC were sharper compared with those of EC due to the different physiological mechanisms that cause the increases. Somatic cell count should be evaluated for inclusion in the EC algorithms, although it has the drawback that automation of its measurement in the milking unit is expensive and not yet sufficiently developed for current use. In addition, SCC of goats can have great variation among days not related to IMI (Zeng et al., 1997).

Milk yield did not decrease significantly after establishment of the infection (data not shown), in contrast to results published by Ying et al. (2004), who observed a reduction of more than $40 \%$ in the production of Saanen and Alpine goats under conditions of IMI. The lack of decrease in the current study probably could be due to most animals developing subclinical infection (only one of the animals had sustained clinical infection and another had clinical infection with rapid recovery), in agreement with results of Leitner et al. (2004), which found a significant reduction in yield if both glands were infected and greater damage to the gland was caused. It implies that the yield variable would not be useful for inclusion in the algorithms of EC for goat IMI detection.

\section{CONCLUSIONS}

The significant increase of EC and SCC in the affected glands observed when infection occurred suggests that the use of IMI detection systems based on daily measurements of EC could allow detection of the disease, especially when greater damage in the gland is observed (e.g., clinical IMI). The system based on daily measurements of EC could be improved if other variables (e.g., SCC) and appropriate algorithms are taken into consideration, as has been done in dairy cows. The daily measurement of EC by gland has the advantage of avoiding factors other than IMI (individual, parity, or stage of lactation) that have effect when a global threshold is proposed or isolated analyses are made. Additionally, EC by gland could be used for automatic IMI detection during milking by installing sensors in the short milk tubes.

\section{ACKNOWLEDGMENTS}

The study was supported by project AGL200606909 (Ministerio de Educación y Ciencia of Spain and FEDER).

\section{REFERENCES}

AOAC. 1995. Official Methods of Analysis. Vol. 2. 16th ed. Association of Official Analytical Chemists International, Arlington. VA.

Barkema, H. W., Y. H. Schukken, T. J. G. M. Lam, D. T. Gallican, M. L. Beiboer, and A. Brand. 1997. Estimation of interdependence among quarters of the bovine udder with subclinical mastitis and implications for analysis. J. Dairy Sci. 80:1592-1599.

Bruckmaier, R. M., C. E. Ontsouka, and J. W. Blum. 2004. Fractionized milk composition in dairy cows with subclinical mastitis. Vet. Med. 49:283-290.

Cavero, D., K. H. Tölle, C. Buxadé, and J. Krieter. 2006. Mastitis detection in dairy cows by application of fuzzy logic. Livest. Prod. Sci. 105:207-213.

Cavero, D., K. H. Tölle, C. Henze, C. Buxadé, and J. Krieter. 2008. Mastitis detection in dairy cows by application of neural networks. Livest. Prod. Sci. 114:280-286.

Cavero, D., K. H. Tölle, G. Rave, C. Buxadé, and J. Krieter. 2007. Analyzing serial data for mastitis detection by means of local regression. Livest. Prod. Sci. 110:101-110.

Christodoulopoulos, G., N. Solomakos, P. D. Katsoulos, A. Minas, and S. K. Kritas. 2008. Influence of oestrus on the heat stability and other characteristics of milk from dairy goats. J. Dairy Res. 75:64-68.

Contreras, A., J. C. Corrales, S. Sánchez, D. Sierra, and J. Marco. 1997. Persistence of subclinical intramammary pathogens in goats throughout lactation. J. Dairy Sci. 80:2815-2819.

Contreras, A., J. C. Corrales, D. Sierra, and J. Marco. 1995. Prevalence and aetiology of non-clinical intramammary infection in Murciano-Granadina goats. Small Rumin. Res. 17:71-78.

De Mol, R. M., A. Keen, G. H. Kroeze, and J. M. F. H. Achten. 1999. Description of a detection model for oestrus and diseases in dairy cattle based on time series analysis combined with a Kalman filter. Comput. Electron. Agric. 22:171-185.

Díaz, J. R., G. Romero, R. Muelas, E. Sendra, J. C. F. Pantoja, and C. Paredes. 2011. Analysis of the influence of variation factors on electrical conductivity of milk in Murciano-Granadina Goats. J. Dairy Sci. 94:3885-3894.

Fernando, R. S., R. B. Rindsig, and S. L. Spahr. 1982. Electrical conductivity of milk for detection of mastitis. J. Dairy Sci. 65:659664

Fernando, R. S., S. Spahr, and E. H. Jaster. 1985. Comparison of electrical conductivity of milk with other indirect methods for detection of subclinical mastitis. J. Dairy Sci. 68:449-456.

Hamann, J., and A. Zecconi. 1998. Evaluation of the electrical conductivity of milk as a mastitis indicator. Bulletin of the IDF 334:5-22.

Harmon, R. J., R. J. Eberhart, D. E. Jasper, B. E. Langlois, and R. A. Wilson. 1990. Microbiological procedures for the diagnosis of bovine udder infection. National Mastitis Council, Madison, WI.

Hillerton, J. E., and A. W. Walton. 1991. Identification of subclinical mastitis with a hand-held electrical conductivity meter. Vet. Rec. 128:513-515.

Holdaway, R. J., C. W. Holmes, and I. J. Steffert. 1996. A comparison of indirect methods for diagnosis of subclinical intramammary infection in lactating dairy cows. Aust. J. Dairy Technol. 51:64-82.

Kamphuis, C., D. Pietersma, R. Van der Tol, M. Wiedemann, and H. Hogeveen. 2008. Using sensor data patterns from an automatic milking system to develop predictive variables for classifying clinical mastitis and abnormal milk. Comput. Electron. Agric. 62:169-181.

Lansbergen, L. M. T. E., M. Nelen, T. J. G. M. Lam, A. Pengov, Y. H. Schukken, and K. Maatje. 1994. Evaluation of a prototype on-line electrical conductivity system for detection of subclinical mastitis. J. Dairy Sci. 77:1132-1140.

Leitner, G., U. Merin, A. Glickman, L. Weisblit, O. Krifucks, S. Shwimmer, and S. Saran. 2004. Factors influencing milk quantity and quality in Assaf sheep and goat crossbreds. S. Afr. J. Anim. Sci. 34(Suppl. 1):162-164. 
Lien, C. C., Y. N. Wan, and H. N. Chen. 2005. Performance evaluation of an online EC measurement system for dairy cow mastitis inspection. Int. Agric. Eng. J. 14:89-99.

Linzell, J. L., and M. Peaker. 1971. The permeability of mammary ducts. J. Physiol. 216:701-716.

Maatje, K., R. M. De Mol, and W. Rossing. 1997. Cow status monitoring (health and oestrus) using detection sensors. Comput. Electron. Agric. 16:245-254.

Maatje, K., P. J. M. Huijsmans, W. Rossing, and P. H. Hogewerf 1992. The efficacy of in-line measurement of quarter milk electrical conductivity, milk yield and milk temperature for the detection of clinical and subclinical mastitis. Livest. Prod. Sci. 30:239-249.

Mele, M, P. Secchiari, A. Serra, G. Ferruzzi, F. Paoletti, and M. Biagioni. 2001. Application of the "tracking signal" method to the monitoring of udder health and oestrus in dairy cows. Livest. Prod. Sci. 72:279-284.

Milner, P., K. L. Page, and J. E. Hillerton. 1997. The effects of early antibiotic treatment following diagnosis of mastitis detected by a change in the electrical conductivity of milk. J. Dairy Sci. 80:859 863.

Nielen, M., Y. H. Schukken, A. Brand, and S. Haring. 1995a. Comparison of analysis techniques for on-line detection of clinical mastitis. J. Dairy Res. 78:1050-1106.
Nielen, M., M. H. Spigt, Y. H. Schukken, H. A. Deluyker, K. Maatje, and A. Brand. 1995b. Application of a neural network to analyse on-line milking parlour data for the detection of clinical mastitis in dairy cows. Prev. Vet. Med. 22:15-28.

SAS Institute. 2002. User's Guide. SAS V.9.1. SAS Institute Inc. Cary, NC.

Yildiz, H., E. Kaygusuzoglu, and H. Simsek. 2006. Somatic cell count, electrical conductivity and biochemical parameters in mastitis milk in cows. Indian Vet. J. 83:498-500.

Ying, C. H., C. H.-B. Yang, and J.-T. Hsu. 2004. Relationship of somatic cell count, physical, chemical and enzymatic properties to the bacterial standard plate count in different breeds of dairy goats. Asian-australas. J. Anim. Sci. 17:554-559.

Zecconi, A., R. Piccinini, G. Giovannini, G. Casinari, and R. Panzeri. 2004. Clinical mastitis detection by on-line measurements of milk yield, electrical conductivity and milking duration in commercial dairy farms. Milchwissenschaft 59:240-244.

Zeng, S. S., E. N. Escobar, and T. Popham. 1997. Daily variations in somatic cell count, composition, and production of Alpine goat milk. Small Rumin. Res. 26:253-260. 